\title{
Investment Attractiveness of Closed-end Real Estate Investment Funds in Russia: Factor Score Evaluation
}

\author{
Irine S. Antonova* \\ Department of Management \\ Tomsk Polytechnic University \\ Tomsk, Russia \\ antonovais@tpu.ru \\ * Corresponding Author
}

Katrine S. Koptelova

Saint-Petersburg State University of Economics

Saint-Petersburg, Russia

katrinakop@yandex.ru

Svetlana N. Popova

Department of Management

Tomsk Polytechnic University

Tomsk, Russia

snp@tpu.ru

\author{
Olesya A. Negodina \\ Department of Criminalistics \\ Tomsk State University \\ Tomsk, Russia \\ Negodina.oa@yandex.ru
}

Lubov Yu. Spitsina

Department of Economics

Tomsk Polytechnic University

Tomsk, Russia

s_luba_07@mail.ru

\author{
Danil D. Vavilov \\ Tomsk Polytechnic University \\ Tomsk, Russia \\ CrystalUS@me.com
}

\begin{abstract}
Closed-end real estate investment fund is currently one of the most popular instruments of collective investments in Russia. In this article, we have designed a factor score method to evaluate the investment attractiveness of closed-end real estate investment funds as the objective of the research. The method differs from others in three elements of attractiveness evaluation: the real estate market, asset management company, and asset portfolio. We suggest evaluating each element by the appropriate factors. In the research, all the factors are grouped and systemized as variable-based and attributebased factors in the three elements of investment attractiveness. The evaluation is based on the expert scores and factor criteria. Results of the research show the differences between preferences of conservative, moderate and aggressive investors when they invest in closed-end investment fund. The desighed method serves for different types of investors to express their attitude to a specific real estate closed-end fund.
\end{abstract}

Keywords-closed-end investment fund; investment attractiveness; real estate market; asset management company; asset portfolio

\section{INTRODUCTION}

Mutual funds have been considered as the basic object of portfolio theory for the at least half a century for they produces the clearest form of asset diversification. Markowitz (1952) prepared one of the most cited publications concerning investments into mutual funds where he evaluated the portfolio of securities in the expected returns and variance [1]. Sharpe (1964) described the capital market equilibrium in terms of the expected rate of return and risk taking into consideration the investor's preference function (total utility function) and the predicted standard deviation [2], [3]. These research works laid the foundation for a capital asset pricing model determining the appropriate structure of the portfolio on the basis of the required rate of return and risk (or standard deviation). Due to the assumptions in the theory the followers of CAPM offer different modifications to include additional factors of the portfolio analysis. Fama and French (1993) converted CAPM model into treefactor model by adding the deduction of big from small and low from high portfolio average returns [4]. The further four-factor model designed by Carhart (1997) considers the "momentum" (the difference between average return on the two high and low prior return portfolios) [5]. The modification of CAPM analysis was offered by Brueggeman, Chen and Thibodeau (1984) who examined the real estate investment funds through its performance [6]. Gallo, Lockwood and Rutherford (2000) highlighted the performance and assets allocation of the real estate investment fund [7]. Studying the performance of real estate mutual funds, Lin and Yung (2004) came to the following conclusion, "a fund size is positively related to risk-adjusted real estate fund performance" [8]. So, the core and most considerable factors of fund investment attractiveness evaluation are 
still a limited set of microeconomic factors, such as performance, risk and allocation of assets both for both open-end (or mutual) and closed-end funds.

Nevertheless the concept of investment attractiveness of a real estate investment fund should include numerous specific factors to consider. Kallberg, Liu, and Trzcinka (2000) defined that managers of a mutual fund added the value by active portfolio management [9]. Hartzell, Sun and Titman (2014) pointed out, that REITs presented significant advantages for testing the influence of managerial quality and incentives on the costs and benefits of diversification [10]. In this case, the attractiveness of an asset management company should be considered as the part of the fund's attractiveness as well as the portfolio itself, its allocation, performance and risk. The other element of the investment attractiveness of a real estate fund is the real estate market, which can dramatically influence on the investment attractiveness of the fund. In this paper, the authors offer to consider the investment attractiveness of a real estate investment fund in three elements: investment attractiveness of the real estate market, investment attractiveness of the asset management company, and investment attractiveness of the assets portfolio. It requires the grouping and systemizing the factors and their indexes (according to the stated elements) to conduct the further evaluation.

\section{REAL ESTATE INVESTMENT FUNDS IN RUSSIA}

Real estate fund in Russia is quite a new financial tool, which first appeared in 2003 and managed by Concordia Asset Management Company. However, it has already become the most widespread type of collective investments. In 2015, 615 real estate investment funds have been registered, which comprises more than $40 \%$ of all investment funds in the country with net asset value of almost 160 billion rubles (\$2,5 billion) or $1 / 3$ of the total net assets of Russian investment funds. At the same time, construction funds have the largest share through all real estate investment funds (about a half of the total net assets).

According to Fecht and Wedow (2014), an open-end real estate fund is the basic tool of real estate investments in Germany as well as in the USA where closed-end fund does not serve the real estate market. Real estate funds in Russia are conversely designed as closed-end funds being a part of so-called "investment funds" accompanying open-end, or mutual, funds. So, the basic difference between Russian and International practice in the definition of the term closed-end fund lies in the legal form of the fund. According to the Russian legislation, the funds investing in real estate must be created only in the closed-end form for a fixed period, which results in lower liquidity of its investment units in comparison with other forms of funds. The closed-end investment fund in Russia is a property complex without a legal entity with its assets invested in real estate for a long-term period (3-15 years) [12-14].

Investment attractiveness here is supposed to be the investor's personal attitude to the investment object in terms of the factors that form the final effectiveness of the investments. Considering the peculiarities of the real estate investment funds in Russia the authors propose to define the investment attractiveness of a real estate investment fund as the variable-based and attributebased factor score that shows specific investor willingness to invest in the specific real estate fund unit. In this case we take into account the tree types of investors: conservative, moderate and aggressive. According to the microeconomic approach the choice of the investor depends basically on risk, return and liquidity preferences. Nevertheless, from the authors' point of view, the list should include more factors systemized and evaluated in a definite way.

\section{METHOD}

In the research the factors are grouped and systemized in the following way:

1) all factors are divided into variable-based and attribute-based factors;

2) all factors are allocated according to the three basic elements of investment attractiveness: the real estate market, asset management company, and assets portfolio;

3) the criterion and the investor specific weight are assigned to every single factor of investment attractiveness;

4) criteria are estimated by 0 or 1 score whereas weights are between 0 and 1 ;

5) total weight in one category equals 1 ;

6) each of the three elements (the real estate market, asset management company, and assets portfolio) has its specific weight of significance in the total index.

The complex index of investment attractiveness of real estate fund for the specific investor is given in the further equation (1).

$$
I=p_{1} \sum_{i=1}^{n} f_{i} * d_{i}+p_{2} \sum_{j=1}^{m} f_{j} * d_{j}+p_{3} \sum_{k=1}^{l} f_{k} * d_{k}
$$

where $f_{i}, f_{j}, f_{k}$ are factor scores of the investment attractiveness for the real estate market, asset management company and assets portfolio respectively; $d_{i}, d_{j}, d_{k}$ are weights of factor significance for the real estate market, asset management company and assets portfolio respectively; $\mathrm{n}, \mathrm{m}, \mathrm{k}$ are the number of estimated factors for the real estate market, asset management company and assets portfolio respectively; $\mathrm{p}_{1}, \mathrm{p}_{2}, \mathrm{p}_{3}$ are weights of investment attractiveness elements, including the real estate market, asset management company and assets portfolio.

The weights of factors and elements are estimated on the basis of 21 respondent (expert) scores. All respondents are private investors or financial specialists. The authors took the deliberate decision to restrict the study to a limited number of respondents to use the most relevant experts in the financial sphere. However, the authors do not insist on this short list, as the method is available for both a single investor and a group of investors. In the first case (for a single investor), the method does not need to deal with the 
representativeness of the sample or the expert score accuracy. In the second case (for a group of investors), on the contrary, the method should consider both sample representativeness and expert score accuracy.

Furthermore, although the expert score method has its clear disadvantages, it serves to overcome the most important problem of complex evaluation including variable-based and attribute-based factors, which implies its estimation in the same units of measure. In this case, attribute-based factors are hardly estimated in numerals except scoring. So, the factor score is considered to be the most appropriate method to attain a target.

\section{RESULTS AND DISCUSSIONS}

The complex index of investment attractiveness of a real estate investment fund requires separate assessment of its elements. The first element to take into account is the real estate market (fig. 1).

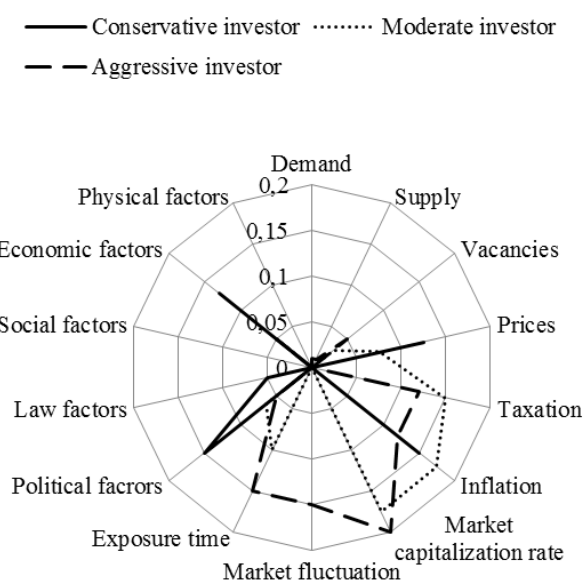

Figure 1. Factor score of the real estate market investment attractiveness

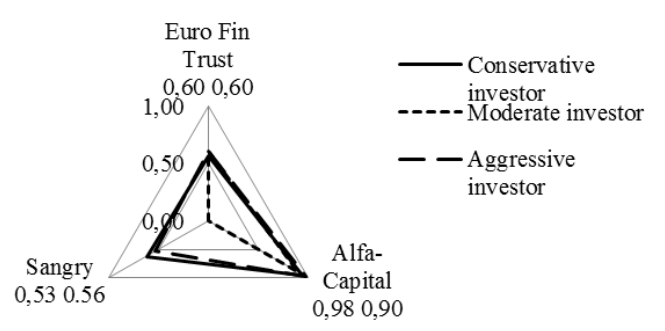

Figure 2. Factor score of the asset management company investment attractiveness factor score
In this work the following factors were grouped and systemized for further evaluation of the real estate market investment attractiveness: variable-based factors are demand, supply, vacancies, prices, taxation, inflation, market capitalization rate, market fluctuation, exposure time; attribute-based factors are political factors, law factors, social factors, economic factors, and physical factors.

The research shows that the most attractive factors for conservative investors are political and economic factors as well as prices and inflation, whereas moderate investors are more interested in inflation, market capitalization rate, and exposure time. At the same time, aggressive investors first take into account the market capitalization rate, market fluctuation, exposure time, taxation, and the rate of inflation.

The second element of investment attractiveness is an asset management company (fig. 2). For the element evaluation, the method offers to group and systemize the following factors: variable-based factors are company total net assets, borrowings, rating, financial and economic performance, net working capital, and liquidity ratio; attribute-based factors are image, work force qualification, history, disclosure, organization, range of funds in management, and the agent network.

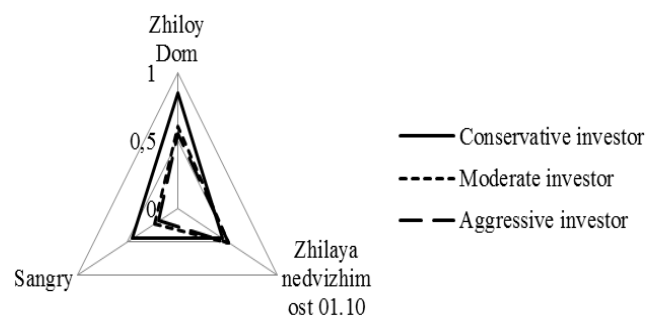

Figure 3. Factor score of the assets portfolio investment attractiveness

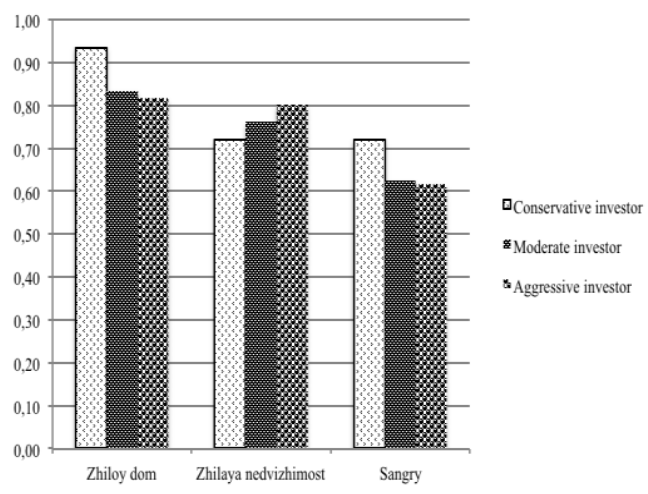

Figure 4. Complex index of real estate fund investment attractiveness 
The research shows that when the conservative investor essentially follows rating, image and work force qualification factors, the moderate investor is interested in financial and economic performance, liquidity ratio, and work force qualification, whereas the aggressive investor focuses on rating, financial and economic performance and liquidity ratio.

In the research, the following companies are chosen: Alfa-Capital, Euro Fin Trust, and Sangry. These companies represent respectively the assets portfolios that are under consideration. The factor score points out that the most attractive asset management company for all three types of investors is Alfa Capital (fig. 2).

The third element of the complex index is the asset portfolio (fig. 3). The factors here are grouped and systemized in the following way: variable-based factors are company net assets value, total property fund, current income, asset management company's reward, depository reward, other expenses, equity value, minimum amount of investments, diversification, management monotony, and liquidity; attribute-based factors are investment policy statement, accessibility for investors, and secondary market circulation. Conservative investors pay attention to the company net asset value, current income, and availability for investors; moderate investors notice current income, asset management company's reward, depository reward, other expenses and secondary market circulation, and aggressive investors are interested in secondary market circulation and management monotony. The results of the evaluation represents the closed-end real estate investment funds "Zhiloy Dom" as the most attractive asset portfolio for the three types of investors (fig. 3).

The complex index is calculated for each type of investors. Thus, final values of the index are presented in fig. 4. The study shows that the conservative investor is more interested in portfolios of real estate funds under consideration rather than the moderate and the aggressive ones. The most important factors of the real estate market for aggressive investors are market capitalization rate, market fluctuation rate, and inflation, whereas the conservative investors focus mostly on economic and political factors as well as inflation. The factor score of three asset management companies by experts corresponds to the position in the rating. However, the final complex index shows only a small extent of Zhiloy Dom scores for all types of investors.

\section{CONCLUSION}

The paper denotes the microeconomic scope as the most widespread approach in the sphere of real estate fund assessment in the recent times. The most frequent factors are currently performance, risk and liquidity. Nevertheless, the authors suggest considering a real estate investment fund wider in terms of the real estate market, asset management company and asset portfolio. The authors offer to estimate these elements on the basis of the expert factor scores. In spite of the disadvantages of the expert score method, it achieves the major goal to estimate variable-based and attribute-based factors in the same measures. The complex index finally helps to show the investors' preferences concerning the specific real estate fund. All steps of the method are useful and representative for the estimation of investment attractiveness.

\section{ACKNOWLEDGMENT}

We would like to thank all of the experts and investors who evaluated the factors of closed-end real estate investment fund that finally helps to estimate the weights of factors and complex index of investment attractiveness.

\section{REFERENCES}

[1] H. Markowitz. "Portfolio selection", The journal of finance, 1952, 7(1), pp. 77-91.

[2] W. F. Sharpe Capital asset prices: A theory of market equilibrium under conditions of risk. The journal of finance, 1964, vol. 19, No3, pp. 425-442.

[3] W.F. Sharpe, "A Simplified Model for Portfolio Analysis," Management Science, Vol. 9, No. 2 (January 1963), pp. $277-$ 293

[4] E. F. Fama and K. R. French "Common risk factors in the returns on stocks and bonds", Journal of financial economics, 1993, vol. 33, №.1, pp. 3-56.

[5] M. M. Carhart "On persistence in mutual fund performance", The Journal of finance, 1997, Vol. 52, №. 1, pp. 57-82

[6] W. B. Brueggeman,., A. H. Chen and T. G. Thibodeau "Real estate investment funds: Performance and portfolio considerations", Real Estate Economics, 1984, 12(3), pp. 333354.

[7] J. G. Gallo, L. J. Lockwood and R. C. Rutherford, "Asset allocation and the performance of real estate mutual funds", Real Estate Economics, 2000, 28(1), pp. 165-185.

[8] C. Lin and \& K. Yung "Real estate mutual funds: performance and persistence", Journal of Real Estate Research, 2004, 26(1), pp. 69-94.

[9] J.G.Kallberg, C.L. Liu, and C. Trzcinka. "The Value Added from Investment Managers: An Examination of Funds of REITs." Journal of Financial and Quantitative Analysis, 2000, vol. 35, pp. 387-408.

[10] J. C. Hartzell, L. Sun and S.Titman, "Institutional investors as monitors of corporate diversification decisions: Evidence from real estate investment trusts", Journal of Corporate Finance, 2014, vol. 25, pp. 61-72.

[11] F. Fecht and M. Wedow, "The dark and the bright side of liquidity risks: Evidence from open-end real estate funds in Germany", Journal of Financial Intermediation, 2011, 23(3), 376-399.

[12] Federal Law “On investment funds" dated 29.11.2001 N 156-FZ (red. of on 29.06.2015). URL: http://www.consultant.ru/docume nt/cons_doc_LAW_34237/

[13] Order of Russian Federation Financial Market Federal Service "On approval of the Regulations on the composition and structure of assets of joint stock investment funds and assets of mutual investment funds" dated 28.12. 2010 No.10 to 79/PZ-n //Bulletin of normative acts of Federal bodies of Executive power, 2011, No.18. URL: http://base.consultant.ru/cons/cgi/onl ine.cgi?req=doc;base=LAW; $=115758$

[14] Order of Russian Federation Financial Market Federal Service "Conserning the Position statement about requirements to the procedure and terms for disclosure of information related to the activities of joint-stock investment funds and management companies of unit investment funds, as well as to the content of disclosed information" (Registered in Ministry of justice of Russia of 19.08.2005 N 6928) dated 22.06.2005 N 05-23/PZ-n (edition from 24.04.2012). URL: http://base.consultant.ru/cons/c gi/online.c gi?req=doc;base=LAW;n=130774 